\title{
Development and evaluation of an inhalation chamber for in vivo tests
}

\author{
EDUARDO R. DA SILVA ${ }^{1}$, HUMBERTO R. BIZZO ${ }^{2}$, PATRÍCIA D. FERNANDES ${ }^{3}$, VALDIR \\ F. DA VEIGA JUNIOR ${ }^{4}$, SUZANA G. LEITÃO ${ }^{1}$ and DANILO R. DE OLIVEIRA ${ }^{1}$
}

\author{
${ }^{1}$ Universidade Federal do Rio de Janeiro, Faculdade de Farmácia, Av. Carlos Chagas Filho, \\ 373, Bloco A, $2^{\circ}$ andar, sala 10, 21941-902 Rio de Janeiro, RJ, Brazil \\ ${ }^{2}$ Embrapa Agroindústria de Alimentos, Av. das Américas, 29501, Guaratiba, 23020-470 Rio de Janeiro, RJ, Brazil \\ ${ }^{3}$ Universidade Federal do Rio de Janeiro, Instituto de Ciências Biomédicas, Av. Carlos Chagas \\ Filho, 373, Bloco K, $2^{\circ}$ andar, sala 35, 21941-902 Rio de Janeiro, RJ, Brazil \\ ${ }^{4}$ Universidade Federal do Amazonas, Departamento de Química, Av. Gal. Rodrigo \\ Octávio Jordão Ramos, 3000, Japiim, 69079-000 Manaus, AM, Brazil
}

Manuscript received on December 5, 2016; accepted for publication on February 24, 2017

\begin{abstract}
The bioavailability, toxicity, and therapeutic efficacy of a drug is directly related to its administration route. The pulmonary route can be accessed by inhalation after fumigation, vaporization or nebulization. Thus, pharmacological and toxicological evaluation accessed by an apparatus specifically designed and validated for this type of administration is extremely important. Based on pre-existing models, an inhalation chamber was developed. This presents a central structure with five animal holders. The nebulized air passes directly and continuously through these holders and subsequently to an outlet. Evaluation of its operation was performed using clove essential oil, a nebulizer, and a flow meter. The air within the chamber was collected by static headspace and analyzed by gas chromatography with a flame ionization detector. For this purpose, a 2.5 minutes chromatographic method was developed. The air flow in each of the five outputs was 0.92 liters per minute. During the first minute, the chamber became saturated with the nebulized material. Homogeneous and continuous operation of the chamber was observed without accumulation of volatile material inside it for 25 minutes. The inhalation chamber works satisfactorily for in vivo tests with medicines designed to be administrated by inhalation.
\end{abstract}

Key words: biological activities, gas chromatograph, headspace, inhalation chamber, Syzygium aromaticum.

\section{INTRODUCTION}

One of the first steps in the development of a medicine is the choice of its administration route. Factors such as bioavailability, toxicity, and therapeutic efficacy are directly related to each of

Correspondence to: Danilo Ribeiro de Oliveira

E-mail: danilopharma@gmail.com the possible administration routes. Considering these issues, the developed medicine can be administered by parenteral, enteral, or topical routes, depending on its site of action, therapeutic effect, and physiological compatibility (York 2005, Prista et al. 2008, Mignani et al. 2013).

Topical administration routes are characterized by the presence of the formulation on the skin 
or mucous surface. These include the pulmonary route, which can be accessed by inhalation after fumigation (traditional use), vaporization, or nebulization. This route allows administration of lower drug concentrations and the therapeutic response onset time is typically shorter (Taylor 2005). This is due to the large pulmonary surface area, which ranges from 80 to $100 \mathrm{~m}^{2}$, and the high permeability of the tracheal and bronchial mucosa and alveolar epithelium, which results from an abundance of capillaries and a small airblood barrier thickness (Taylor 2005). The large contact surface and high permeability allows rapid absorption of volatiles and small-diameter particles or droplets (Prista et al. 2008). Dispersion of this micronized material can be accomplished with nebulizer devices, which offer advantages such as administration in breathing rate and ease of use by children and elderly people (Taylor 2005). These droplets and particles can act locally or be absorbed by entering the small circulation and later the general one, and they do not undergo the first-pass effect (Prista et al. 2008).

Every new drug under development must undergo preclinical studies with animals to evaluate its pharmacological activity as well as being subjected to toxicological and pharmacokinetic studies (WHO 2005). To this end, the use of an inhalation chamber enables in vivo studies by mimicking clinical use of the drug, and it is of the utmost importance in the development of a medicine designed for pulmonary administration. Such an apparatus is also important in evaluating the toxicity of smokes and vapors encountered in human daily life, such as cigarette smoke (Shimazu et al. 1990, 1996, Sakano 1993, Lalonde et al. 1994, Valença et al. 2004, 2006). Matthew et al. (2001) used a model similar to that proposed in this study to assess lung damage caused by inhalation of smoke derived from burning wood, as well as during fire events.
The first models used in previous studies by other research groups consisted of glass bottles with volumes ranging from 2 to $4 \mathrm{~L}$ with no output to the inflated air. Camara (1967) used similar bottles with a side exit where animals were placed to inhale, while Carlini (1973) placed the animals inside these bottles to inhale. Since then, new models have emerged to evaluate the effect of inhalation of different types of materials (Rihn et al. 1996, Matthew et al. 2001). Recently, inhalation boxes were used, which contained pieces of cotton moistened with the studied material, and these were fixed at the top of the walls of the flask (Komyia et al. 2006); alternatively, filter-paper discs were moistened with these materials and secured to the flask walls (Takemoto et al. 2008, 2009, Ito and Ito 2011). Tests were also conducted on square chambers with electronic vaporizers (Bradley et al. 2007), chambers with evaporators connected to an oxygen feeder (Shaw et al. 2007), and glass cylindrical chambers containing four animal holders fixed to the sides with two tubes for adapting electronic nebulizers (Linck et al. 2010).

Some inhalation chamber designs were also found in patent banks. In Brazil, two patents have been applied for on hyperbaric inhalation chambers, in which the test material is placed together with the animals. One is portable (Pereira 2004), and the other is of a larger size for use only in a laboratory (Lopes 2004). Four other documents were found in the US patent bank, which all involved the individual arrangement of a large number of animals (Bung et al. 1984, Vincent and Guénette 1997, Schenkel et al. 2009), except for that deposited by Hemenway and Stedman (1981). There is also a patent in the databank relating to an inhalation chamber with ten animal holders and a helix for homogenization of the air inside it (Lastow 2010).

In this study, we present the development of an inhalation chamber that enables toxicological and pharmacological tests using animals. Furthermore, 
we also evaluate the behavior during its operation with clove essential oil when coupled to a nebulizer.

\section{MATERIALS AND METHODS}

\section{CHEMICALS, REAGENTS, AND STOCK SOLUTIONS}

Toluene, ethanol $96^{\circ}$, and propylene glycol were purchased from Spectrum (SP, BRAZIL). Clove essential oil [Syzygium aromaticum (L.) Merr. \& L.M. Perry] was supplied by Mane do Brasil (RJ, BRAZIL). Distilled water was prepared in-house with a distiller.

\section{INHALATION CHAMBER DEVELOPMENT}

Development of the inhalation chamber started, as is usual, with a literature review on devices currently being used for similar purposes. A survey was conducted of academic books, patent databases, and databases containing scientific articles. Chamber, inhalation, apparatus, nebulization, and vaporization were the words used during the search. These were employed in both Portuguese and English, individually and in association.

After reviewing these data, three modified chamber configurations were drawn, and one of these was selected for initial trials.

\section{OPTIMIZATION OF AN ANALYTICAL METHOD}

Clove essential oil was used to evaluate the behavior of the chamber during operation. A gas chromatography (GC) method was adapted for a short-time analysis, and two gas chromatographs, operating under the same conditions in parallel, were used to evaluate the time needed for chamber saturation. Each gas chromatograph, Agilent 7890 A, was fitted with a flame ionization detector (GC-FID). Separation was accomplished with an HP-5 fused silica capillary column (5\% phenyl, $95 \%$ methylsiloxane) $(30 \mathrm{~m} \times 0.25 \mathrm{~mm}$ i.d., 0.25 $\mu \mathrm{m}$ phase thickness). Operating conditions were as follows: split ratio 1:20; injector temperature $250^{\circ} \mathrm{C}$; carrier gas: hydrogen, $5.0 \mathrm{~mL} / \mathrm{min}$, constant flow; column temperature $160^{\circ} \mathrm{C}$ (no hold), $20^{\circ} \mathrm{C}$ per minute to $200^{\circ} \mathrm{C}$; detector temperature $280^{\circ} \mathrm{C}$. An essential oil droplet was diluted in toluene to 1 $\mathrm{mL}$ and $1 \mu \mathrm{L}$ of this solution was injected.

\section{EVALUATION OF THE INHALATION CHAMBER OPERATION}

The behavior of the chamber in operation with a nebulizer was evaluated by GC. First, an aqueous dispersion containing $0.5 \%(\mathrm{v} / \mathrm{v})$ of clove essential oil, $10 \%(\mathrm{v} / \mathrm{v})$ of propylene glycol, and $10 \%(\mathrm{v} / \mathrm{v})$ of ethanol was prepared; $15 \mathrm{~mL}$ of this dispersion was placed into the nebulizer cup and this was coupled to the inhalation chamber.

Inside the chamber, air samples $(100 \mu \mathrm{L})$ were collected by static headspace using a Hamilton Bonaduz AG syringe, Microliter ${ }^{\mathrm{TM}}$ Syringes, $2.500 \mu \mathrm{L}$ (Figure 1a and Figure 3 - sampling port). Samples were collected every odd minutes from 1 to 25 minutes and were directly injected and analyzed by GC-FID. This assay was performed in triplicate, and between each test, the chamber, silicone hose, and nebulizer cup were washed with acetone, ethanol, and water and dried in an oven for 30 minutes.

\section{EVALUATION OF THE INHALATION CHAMBER AND HEADSPACE SYRINGES CLEANING PROCESSES BETWEEN ANALYSES}

Before any test and between each chamber analysis, a blank test was conducted by injecting $100 \mu \mathrm{L}$ of the air inside the chamber without the test solution. These tests were important to verify the absence of carryover from oil samples or residual washing solvents.

Furthermore, these blank tests also allowed the evaluation of any carryover from the syringe, and test results were used to establish the number of piston-pumping cycles required to eliminate all volatile residues inside the syringe. Thus, after collect and inject $100 \mu \mathrm{L}$ of essential oil dispersion nebulized inside the chamber, 10, 30, and 50 
displacements were performed with the piston syringe and then, after each of these cycles, $100 \mu \mathrm{L}$ of the air from the syringe was injected into the GC. All testing procedures were performed in triplicate.

EVALUATION OF THE NEBULIZED AIR FLOW WITHIN THE CHAMBER

The nebulized air flow within the chamber was measured with a Cole-Parmer 32900-46 flowmeter, which was capable of measuring air flow in the range of 0.4 to 5.0 liters per minute (LPM). To this end, four of five outputs of the chamber were closed and the flowmeter was attached to the one that was open. The air flow value indicated by the flowmeter was divided by 5 (total outputs) so that the air flow for each output was calculated.

\section{RESULTS AND DISCUSSION}

\section{DEVELOPED INHALATION CHAMBER STRUCTURE}

Based mainly on the system used by Linck et al. (2010), a rounded-wall inhalation chamber was developed with a reduced central inner space in order to decrease the inlet air dissipation, resulting in better utilization of the test material due to rapid chamber saturation. This central part (Figure 1a) consists of an Erlenmeyer glass flask with a female abraded joint at the upper portion and five others on the side, in which animal holders (Figure 1c) are embedded. Each of these lateral joints has two lateral hooks for attaching elastic bands to prevent loss of the lids of the animal holders (Figure 1b) during tests with animals. The central part has an outlet for air collection, known as a sampling port, which has a threaded plastic cap with a septum to avoid air loss during in vivo tests. This is a great advantage over the other apparatus cited in this work, which either had no sample port at all (the system must be opened if the inside air is to be sampled) or had one in the animal compartment. Such proximity can allow animal contaminants, such as volatile urine and feces components, to enter the collected air, introducing artifacts into the $\mathrm{GC}$ analyses.

Animal holders (Figure 1c) are coupled to the female abraded joints located at the side of the central part. These compartments may vary in diameter and length according to the animal size (mouse or rat) and weight or the type of test to be performed (Sizes of the glass joints and dimensions of each piece of glassware developed for the use with mice are presented in the Figures S1 to S5 Supplementary Material. It is important that the diameter is large enough to present no discomfort to the animal, while being small enough to prevent direction change. Its cylindrical structure, with a narrowing in the front coupling joint, allows insertion of the animals' muzzles, resulting in direct administration of the nebulized air. The connection with the central part is achieved with male abraded joints, which have no leak points and are easy to fit and remove for cleaning. At the rear of these compartments, another male abraded joint is used for fitting of the lid. A large aperture at this location (distal part of the chamber) is important to enable both introduction and removal of the animal. After placing the animals in each animal holder, the lids are fitted, preventing the animals from escaping from the chamber during inhalation tests. All animal holders are removable, facilitating cleaning and reducing the risk of breakage of the glass apparatus, which is an advantage when compared to the system developed by Linck et al. (2010). Furthermore, all of these animal holders are aligned at the same height relative to the central chamber, which prevents the variation in the nebulized material provided for each animal that occurred in other models (Hemenway and Stedman 1981, Bung et al. 1984). This probably occurred as a result of rapid settling of some nebulized materials, favoring inhalation by animals located at lower points in these chamber models.

As the lateral female abraded joints of the central part, each of these animal holder lids also 
has two hooks on its side (Figure 1b), which are important for attachment of the elastic bands. Each lid has a female abraded joint at one of its borders and an air output at another, which can be sealed with a plastic screw cap. These outputs are opened during the tests, forcing the intake air to leave the chamber through them, since they are the only exits of the chamber. This ensures that all intake air is distributed from the central part of the chamber to the animal holders and thence to the outside of the chamber. This constant and unidirectional flow carries body smells, excrement smells, and gases expelled by the animals themselves, preventing them from contaminating the internal environment of the chamber. Constant air renewal into the chamber is an advantage compared to chambers working with controlled pressure (Hemenway and Stedman 1981, Lopes 2004, Pereira 2004), those which do not have unidirectional flow, in which the chamber air outlet is near to the entrance (Bung et al.1984, Vincent and Guénette 1997, Schenkel et al. 2009), and inhalation boxes (Valença et al. 2004, 2006, Komyia et al. 2006, Bradley et al. 2007, Takemoto et al. 2008, 2009, Ito and Ito 2011).

To the upper female abraded joint present on the central part is coupled the chamber "head," which is responsible for receiving and distributing the air inside the chamber (Figure 1d). This section comprises an upper entrance with rings of different diameters for coupling of a silicone hose.

After the curve of the inlet tube, there is a male abraded joint responsible for coupling the "head" to the central part of the chamber, which avoids loss of admitted materials. The central tube, through which the air passes, extends from the "head" to the bottom of the chamber and releases the air near to the chamber base; this generates a vortex that optimizes saturation and allows more uniform air distribution to the animals.

A silicone hose is attached to the "head" and to a glass junction (Figure 1e) at the other border. As the chamber "head," this cylindrical glass junction presents a joint with rings for coupling the silicone hose and another smooth joint for coupling to the nebulizer cup.

The use of only glass parts is another significant advantage of this developed chamber since these can be washed and sterilized, which eliminates residues and contaminants that could interfere with future trials. The small silicone hose, nebulizer cup, and septum are exceptions to this and these should be replaced for each new analysis to avoid contamination.

The chamber can be attached to a nebulizer or another source of volatile liquid, smoke, or combustion products for its operation. For this study, only a nebulizer device or another source of steam is required for its operation. The estimated cost for chambers that require more than one test material source (Linck et al. 2010) is higher as another nebulizer is required in addition to twice the amount of test material.

Activation of the nebulizer allows air to be injected into the cup containing the formulation, which in turn is nebulized and delivered to the glass joint (Figure 1e). From this joint, the nebulized material passes through the silicone hose and reaches the "head," which is responsible for admission of the nebulized air into the chamber (Figure 1d). Thus, nebulized air is introduced through the central tube of this section into the central part of the chamber, creating a vortex. None of the other devices mentioned in this work, which were used in in vivo inhalation assays, used this method of distributing material to the animals. Turbulence generated in the bottom of the chamber allows air to be uniformly distributed to each animal holder, avoiding differences in the doses administered to the animals. Beyond the vortex, nebulized air is directed to the tubes in which the animals are placed (Figure 1c). Thus, the animals inhale the test material (formulations, vapors or smoke), while exhaled air and odors are emitted from the chamber. The continuous air feed to the 
a
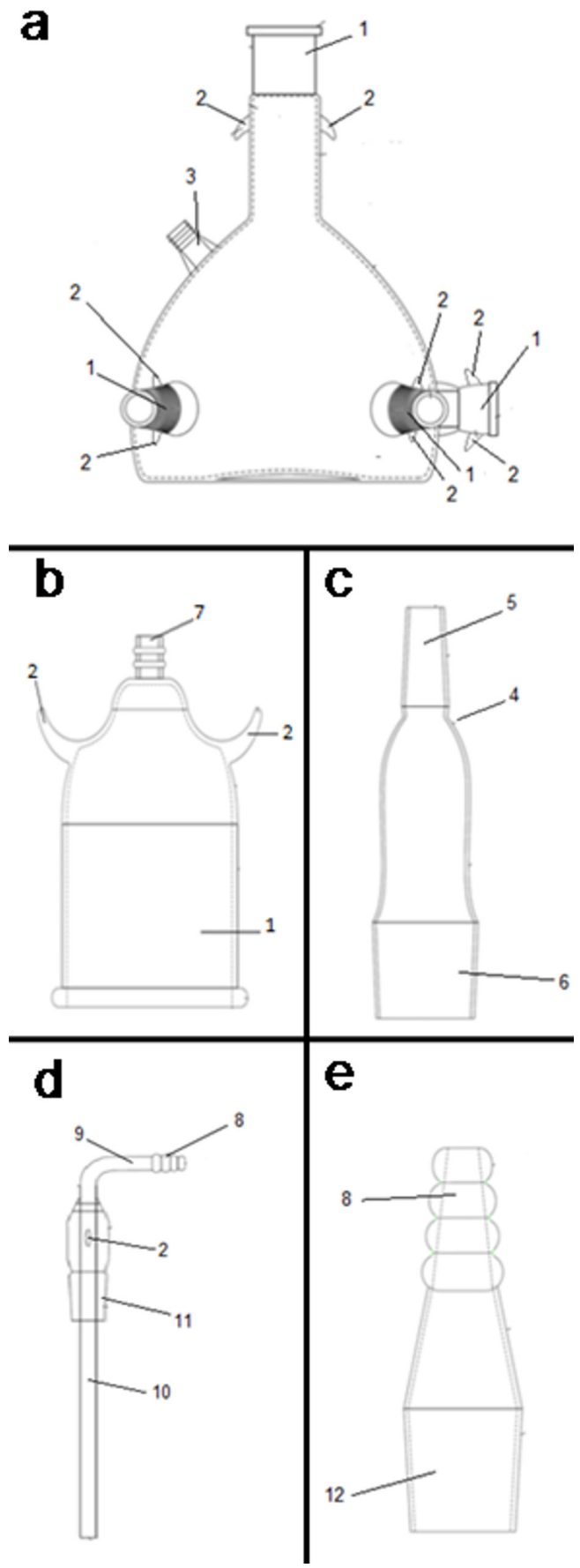

Figure 1 - Inhalation chamber sections. (a) Central part. (b) Lid. (c) Animal holder. (d) "Head". (e) Glass joint. 1) female abraded joints; 2) lateral hook; 3) sampling port; 4) tube narrowing; 5) front male abraded joint; 6) distalfemale abraded joint; 7) air output; 8) entrance with rings; 9) inlet tube; 10) central tube; 11) male abraded joint; 12) smooth for coupling to the nebulizer cup. chamber causes the air to be constantly changed in this environment, since incoming air expels the air already present in the chamber through holes in the lids of the animal holders (Figure 1b), avoiding supersaturation and environmental contamination. Figure 2 presents the inhalation chamber coupled to a nebulizer.

\section{ANALYTICAL METHOD OPTIMIZATION PROCESS}

After the development of the inhalation chamber, it was necessary to test its practical operation. Clove essential oil was used to evaluate this process since it contains few compounds (Figure 3), which would lead to well defined chromatograms that would be simple to compare.

The quantification of the three major components of clove essential oil - eugenol $(85.0 \%)$, eugenol acetate $(4.8 \%)$, and caryophyllene $(10.3 \%)$, led to the development of a faster and more effective method of quantifying these components. Considering that in previous analysis eugenol eluted at approximately 20 minutes, with an initial oven temperature of $60^{\circ} \mathrm{C}$ and a heating rate of $3^{\circ} \mathrm{C} / \mathrm{min}$, it must have eluted at around $120^{\circ} \mathrm{C}$. Therefore, the next run was started with an oven temperature of $120^{\circ} \mathrm{C}$ with $2 \mathrm{~min}$ isotherm, followed by a $20^{\circ} \mathrm{C} /$ min heating rate to $200^{\circ} \mathrm{C}$ totaling a 6-minute run (Figure 3a). The gas flow was also increased to 3 $\mathrm{mL} / \mathrm{min}$ in order to decrease the elution time of the dead volume.

Because the chromatogram presented well defined and isolated peaks (Figure 3a) with eugenol eluting at 3.671 minutes, a new attempt was made to further reduce the running time. Thus, the initial oven temperature was raised to $150^{\circ} \mathrm{C}$ with a 1 minute isotherm followed by a $20^{\circ} \mathrm{C} / \mathrm{min}$ heating rate to $200^{\circ} \mathrm{C}$, totaling a 3.5 minute run (Figure $3 \mathrm{~b})$. The gas flow was also increased to $5 \mathrm{~mL} / \mathrm{min}$. Again, the chromatogram presented well defined peaks with eugenol eluting at 1.673 minutes. 


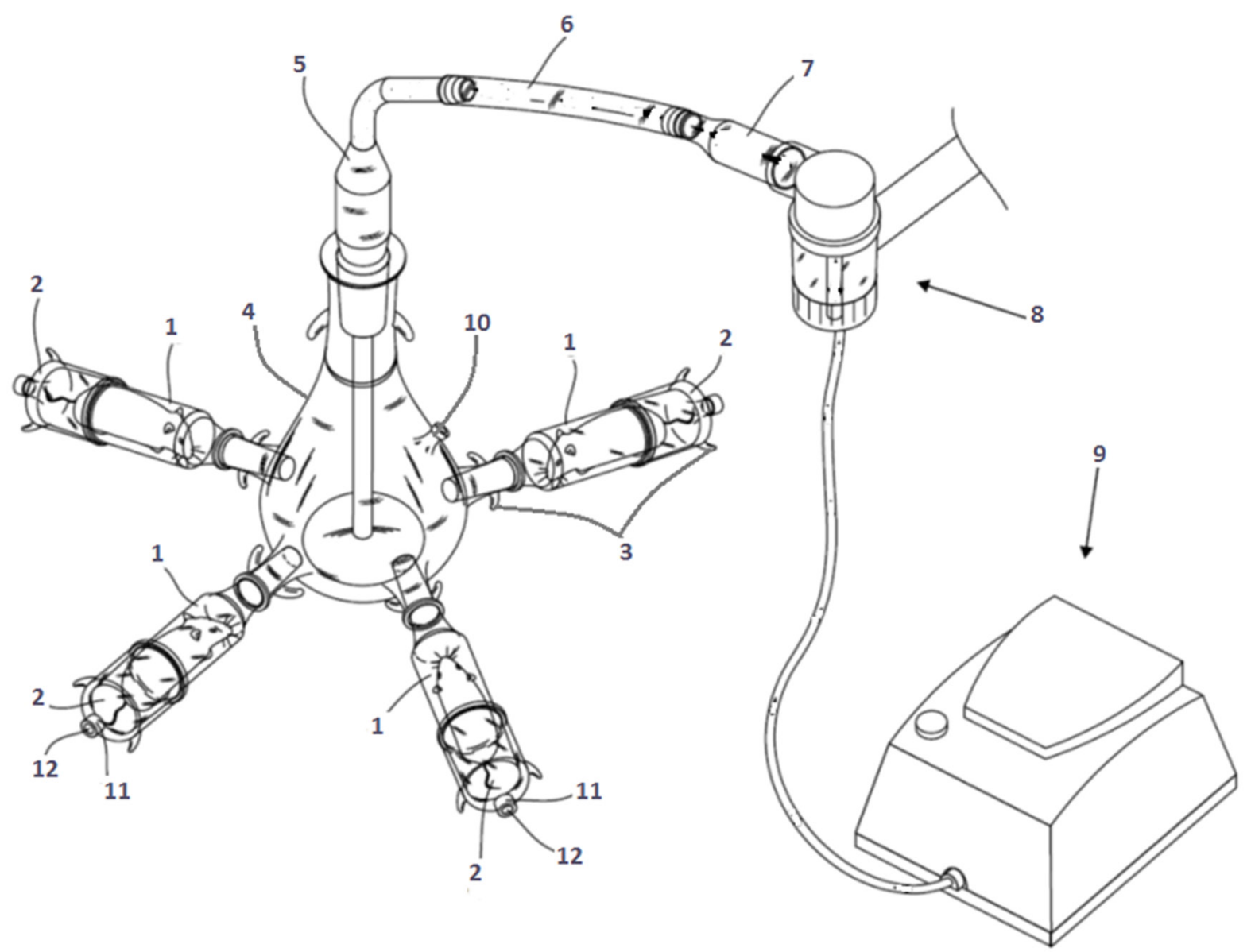

Figure 2 - Inhalation chamber coupled to a nebulizer. 1) animal holder; 2) lid; 3) lateral hooks; 4) central part; 5) "head"; 6) silicone hose; 7) glass joint; 8) nebulizer cup; 9) nebulizer; 10) sampling port; 11) plastic screw cap; 12) air output.

As all the components were eluted at $174^{\circ} \mathrm{C}$ (2.054 minutes), another method was tried with the run finishing at $180^{\circ} \mathrm{C}$. Thus, another attempt was initiated with the oven at $160^{\circ} \mathrm{C}$, without isotherms, with a $20^{\circ} \mathrm{C} / \mathrm{min}$ heating rate to $180^{\circ} \mathrm{C}$ and a gas flow of $5 \mathrm{~mL} / \mathrm{min}$ (Figure 3c). This method resulted in a 2.5 minute run with three well defined majority peaks presenting areas close to those obtained by the first method used.

This rapid method provided an assessment of the inhalation chamber operation, since by working with two chromatographs simultaneously, it was possible to analyze the air nebulized inside the chamber every 2 minutes. Furthermore, all gas chromatographic methods found in the literature and employed for this essential oil analysis are slower; hence, this is probably the fastest method developed to date (Jirovetz et al. 2006, Alma et al. 2007, Chaieb et al. 2007, Scherer et al. 2009, Hajlaoui et al. 2010, Silvestri et al. 2010).

\section{EVALUATION OF CARRYOVER AND CLEANING PROCEDURES}

The carryover in the syringe used was tested by injecting a $100 \mu \mathrm{L}$ sample of the pumped air into the headspace syringe. It was observed that after 10 pumping cycles, the chromatogram of a blank injection contained only solvent residues with no 




Figure 3 - Clove essential oil GC-FID chromatograms obtained during analytical method improvement for the evaluation of the inhalation camera operation. a. $6 \mathrm{~min}$ run $(\mathrm{ERt}=3.671$, $\mathrm{EARt}=4.221$ and $\mathrm{CRt}=4.956)^{*}$; b. $3.5 \mathrm{~min}$ run $(\mathrm{ERt}=1.390$, EARt $=1.673$ and $\mathrm{CRt}=2.054)$; c. 2.5 min run $(E R t=1.163$, EARt $=1.349$ and $C R t=1.586)$.

$*$ ERt $=$ Eugenol retention time $(\mathrm{min}) ; \mathrm{EARt}=$ Eugenol Acetate retention time $(\mathrm{min}) ; \mathrm{CRt}=$ Caryophyllene retention time ( $\mathrm{min})$.

trace of clove essential oil (Figure S6). Therefore, it was established that 10 pumping cycles for the syringe between samplings represented an acceptable cleaning procedure.

The cleaning procedure of the glass parts involved washing with acetone and ethanol followed by a final rinse with distilled water. All glassware was dried in an oven. After a test with clove essential oil and washing, a blank test was performed and the air in the chamber was collected by headspace and injected into the GC to evaluate carryover. Again, only solvent residues were observed, indicating that this was an efficient cleaning method.

The air flow inside the chamber was measured by means of a flowmeter coupled to a single animal tube with an open output. To estimate the flow for each animal compartment, the total flow must be divided by the number of animals or tubes being used (maximum: 5). First, a flow of 4.6 LPM was observed. Therefore, this value was divided by five (number of chamber outputs), resulting in a 0.92 LPM nebulized air flow for each of the animal holders.

\section{SATURATION TIME}

The air inside the chamber during a nebulization test with clove oil was sampled every two minutes from 1 to 25 minutes. Air from the headspace was injected into the GC. It was observed that, from the first minute, the air inside the chamber was already saturated (steady state) (Figures S7 and S8). This leads to two conclusions. Firstly, the air composition inside the chamber was homogeneous during the test, with no increase in the composition of volatiles due to condensation in the internal 
walls followed by revolatilization; secondly, the animal compartments can be coupled from the very beginning of the test, without presaturation of the chamber. The test time can be measured from the start of nebulization, so that no preconditioning time is needed.

Due to the fast saturation of the atmosphere throughout the chamber, a waiting time is not required before initiating the tests. This is interesting from a practical point of view, since all the animals can be placed in the chamber before turning on the nebulizer. This prevents animals from being inserted while the camera is in operation as this triggers a difference in the dose administered to each animal. Moreover, the homogenous operation of the apparatus avoids accumulation of material, which prevents the administration of overdoses to the animals.

These situations are probably not observed in inhalation boxes with cotton or filter-paper moistened with the volatile test material (Komyia et al. 2006, Bradley et al. 2007, Takemoto et al. 2008, 2009, Ito and Ito 2011). These require an initial time for saturation of the internal environment and subsequent animal placement since volatilization is a slow process, which is necessary for operation of the apparatus.

Furthermore, apparatus containing an inhalation box (Valença et al. 2004, 2006, Komyia et al. 2006, Bradley et al. 2007, Takemoto et al. 2008, 2009, Ito and Ito 2011) and those that do not present a unidirectional flow of insufflated material (Hemenway and Stedman 1981, Bung et al. 1984, Vincent and Guénette 1997, Lopes 2004, Pereira 2004, Schenkel et al. 2009) are prone to the accumulation and deposition of such test materials. This may result in the administration of more than the required dose due to both accumulation inside the chamber and deposition on the animals' bodies. In addition to presenting a unidirectional flow in the developed chamber, its reduced diameters are compatible with the animal's size, preventing it from licking itself and ingesting condensed material, volatiles, and aqueous droplets that lie on its fur.

\section{CONCLUSIONS}

The present study demonstrated that the inhalation chamber works satisfactorily for in vivo tests with drugs and formulations designed to be administrated by inhalation. It does not require a waiting time for saturation and subsequent insertion of animals since, from the first minute, the concentration of volatiles in its internal atmosphere does not vary.

Its operation with a unidirectional and permanent air flow avoids dosage errors during evaluation of medicinal products. In addition, the feasibility of determining the air flow allows correct calculation of the dose and inhalation time.

Considering that the chamber developed in the present study operates as expected and may mimic clinic use, this apparatus is a promising tool for preclinical tests necessary for the design of new medicaments administered by inhalation. Furthermore, it can also be considered for toxicological evaluation of smokes and fumigations.

\section{ACKNOWLEDGMENTS}

This work was supported by Empresa Brasileira de Pesquisa Agropecuária (Embrapa), Universidade Federal do Rio de Janeiro (UFRJ) and Conselho Nacional de Desenvolvimento Científico e Tecnológico (CNPq) (Universal 453893/2014-7). The authors thank the UFRJ Innovation Agency, Mr. Renato Salvi for the clove oil sample and Mr. André Luis do Nascimento for the drawings of the chamber.

\section{REFERENCES}

ALMAMH, ERTAS M, NITZSAND KOLLMANNSBERGER H. 2007. Chemical composition and content of essential oil from the bud of cultivated Turkish clove (Syzygium aromaticum L.). Bio Resources 2: 265-269. 
BRADLEY BF, STARKEY NJ, BROWN SL AND LEA RW. 2007. The effects of prolonged rose odor inhalation in two animal models of anxiety. Physiol Behav 92: 931-938.

BUNG R, GIESBRECHT H, LEUCKEL W AND KLIMISCH HJ. 1984. Respiratory nose-only device and system for laboratory animals, US pat. 4.479.493, http://patft.uspto. gov/netahtml/PTO/srchnum.htm.

CAMARA SA. 1967. Manual de farmacologia prática, São Paulo: Atheneu, 175 p.

CARLINI EA. 1973. Farmacologia prática sem aparelhagem, São Paulo: Sarvier, 198 p.

CHAIEB K, HAJLAOUI H, ZMANTAR T, KAHLANAKIB AB, ROUABHIA M, MAHDOUANI K AND BAKHROUF A. 2007. The chemical composition and biological activity of clove essential oil, Eugenia caryophyllata (Syzygium aromaticum L. Myrtaceae): a short review. Phytother Res 21: 501-506.

HAJLAOUI H, SNOUSSI M, NOUMI E, ZANETTI S, KSOURI R AND BAKHOUF A. 2010. Chemical composition, antioxidant and antibacterial activities of the essential oils of five Tunisian aromatic plants. Ital J Food Sci 22: 320-329.

HEMENWAY DR AND STEDMAN LA. 1981. Inhalation toxicology chamber, US pat. 4.305.347, http://patft.uspto. gov/netahtml/PTO/srchnum.htm.

ITO K AND ITO M. 2011. Sedative effects of vapor inhalation of the essential oil of Microtoena patchoulii and its related compounds. J Nat Med 65: 336-343.

JIROVETZ L, BUCHBAUER G, STOILOVA I, STOYANOVA A, KRASTANOV A AND SCHMIDT E. 2006. Chemical composition and antioxidant properties of clove leaf essential oil. J Agric Food Chem 54: 6303-6307.

KOMYIA M, TAKEUCHI Y AND HARADA E. 2006. Lemon oil vapor causes an anti-stress effect via modulating the 5-HT and DA activities in mice. Behav Brain Res 172: 240-249.

LALONDE C, PICARD L, CAMPBELL C AND DEMLING R. 1994. Lung and systemic oxidant and antioxidant activity after graded smoke exposure in the rat. Circ Shock 42: 7-12.

LASTOW O. 2010. Apparatus and method for exposing laboratory animals to a test substance, WIPO pat. WO 2010/002331 A1, https:/patentscope.wipo.int/search/en/ search.jsf.

LINCK VM, DA SILVA AL, FIGUEIRÓ M, CAMARÃO EB, MORENO PR AND ELISABETSKY E. 2010. Effect of inhaled linalool in anxiety, social interaction and aggressive behavior in mice. Phytomedicine 17: 679-683.

LOPES MAS. 2004. Câmara hiperbárica, BR pat. MU 8300606-0 U, https://gru.inpi.gov.br/pePI/jsp/patentes/ PatenteSearchBasico.jsp.
MATTHEW E, WARDEN G AND DEDMAN J. 2001. A murine model of smoke inhalation. J Physiol Lung Cell Mol Physiol 280: 716-723.

MIGNANI S, KAZZOULI SE, BOUSMINA M AND JEANPIERRE M. 2013. Expand classical drug administration ways by emerging routes using dendrimer drug delivery systems: A concise overview. Adv Drug Deliv Rev 65: 1316-1330.

PEREIRA MLL. 2004. Câmara hiperbárica portátil para uso em experimentos em animais, BR pat. MU 8202611-4 U, https://gru.inpi.gov.br/pePI/jsp/patentes/ PatenteSearchBasico.jsp.

PRISTA LN, ALVES AC, MORGADO R AND LOBO JS. 2008. Tecnologia Farmacêutica, $7^{\text {th }}$ ed., Fundação Calouste Gulbenkian, Lisbon, PT, p. 41-194.

RIHN B, KAUFFER E, MARTIN P, COULAIS C, VILLA M, BOTTIN MC, VIGNERON JC, EDORH A AND MARTINET N. 1996. Short-term crocidolite inhalation studies in mice: validation of an inhalation chamber. Toxicol 109: 147156.

SAKANO T. 1993. A rabbit model of inhalation injury. J Trauma 34: 411-416.

SCHERER R, WAGNER R, DUARTE MCT AND GODOY HT. 2009. Composição e atividades antioxidante e antimicrobiana dos óleos essenciais de cravo-da-índia, citronela e palma rosa. Rev Bras Plant Med 11: 442-449.

SCHENKEL AR, SCHROEDER WG AND VOLCKENS J. 2009. System for small animal aerosol inhalation chamber, US pat. $0211534 \mathrm{~A} 1$, http://patft.uspto.gov/netahtml/PTO/ srchnum.htm.

SHAW D, ANNETT JN, DOHERTY B AND LESLIE JC. 2007. Anxiolytic effects of lavender oil inhalation of openfield behavior in rats. Phytomedicine 14: 613-620.

SHIMAZU T, IKEUCHI H, HUBBARD G, LANGLINAIS P, MASON AD AND PRUITT BA. 1990. Smoke inhalation injury and the effect of carbon monoxide in the sheep model. J Trauma 30: 170-175.

SHIMAZU T, YUKIOKA T, IKEUCHI H, MASON AD, WAGNER PD AND PRUITT BA. 1996. Ventilationperfusion alterations after smoke inhalation in an ovine model. J Appl Physiol 81: 2250-2259.

SILVESTRI JDF, PAROUL N, CZYEWISK E, LERIN L, ROTAVA I, CANSIAN RL, MOSSI A, TONIAZZO G, DE OLIVEIRA D AND TREICHEL H. 2010. Perfil da composição química e atividades antibacteriana e antioxidante do óleo essencial do cravo-da-índia (Eugenia caryophyllata Thunb.). Rev Ceres 57: 589-594.

TAKEMOTO H, ITO M, SHIRAKI T, YAGURA T AND HONDA G. 2008. Sedative effects of vapor inhalation of agarwood oil and spikenard extract and identification of their active components. J Nat Med 62: 41-46.

TAKEMOTO H, YAGURA T AND ITO M. 2009. Evaluation of volatile components from spikenard: valerena-4,7(11)- 
diene is a highly active sedative compound. J Nat Med 63: 380-385.

TAYLOR P. 2005. Liberação Pulmonar de Fármacos. In: Aulton ME. Delineamento de Formas Farmacêuticas, $2^{\text {nd }}$ ed., Porto Alegre: Artmed Editora S.A., p. 478-493.

VALENÇA SS, CASTRO P, PIMENTA WA, LANZETTI M, SILVA SV, BARJA-FIDALGO C, KOATZ VLG AND PORTO LC. 2006. Light cigarette smoke-induced emphysema and NFאB activation in mouse lung. Int J Exp Pathol 87: 373-381.

VALENÇA SS, DA HORA K, CASTRO P, MORAES VG, CARVALHO L AND PORTO LC. 2004. Emphysema and Metalloelastase Expression in Mouse Lung Induced by Cigarette Smoke. Toxicol Pathol 32: 351-356.
VINCENT R AND GUÉNETTE J. 1997. Inhalation apparatus for test animals, US pat. 5,626,130,http://patft.uspto.gov/ netahtml/PTO/srchnum.htm.

WHO. 2005. Operational guidance: Information needed to support clinical trials of herbal products. World Health Organization on behalf of the Special Program for Research and Training in Tropical Diseases.

YORK P. 2005. Delineamento de Formas Farmacêuticas. In: Aulton ME. Delineamento de Formas Farmacêuticas, $2^{\text {nd }}$ ed., Porto Alegre: Artmed Editora S.A., p. 17-28.

\section{SUPPLEMENTARY MATERIAL}

Figures S1 - S8 